\title{
Trademark dilution: comparing the effects of blurring and tarnishment cases over brand equity
}

\author{
Washington MACÍAS \\ Escuela Superior Politécnica del Litoral, ESPOL, Facultad de Ciencias Sociales y Humanísticas, \\ Guayaquil, Ecuador \\ wamacias@espol.edu.ec \\ Julio CERVIÑo \\ Universidad Carlos III de Madrid, Spain, and Universidad ESAN, Lima, Peru
}

\begin{abstract}
Trademark dilution is, in a general sense, a reduction in brand equity due to the unauthorized use of the trademark by third parties (junior brands). Although there are two types of dilution, blurring and tarnishment, existing academic empirical evidence only relates to blurring cases, showing its damage to some variables related to brand associations in consumers' minds. Literature also shows the moderating role of the similarity between junior brands, but this evidence is not complete unless presumable tarnishment cases are analyzed. This paper compares the effect of two types of junior brands over strength of associations and brand equity of famous trademarks. An experimental approach was applied with a sample of 372 undergraduate students, users of two famous convenience brands. Junior brands use identical or similar famous brand names in different product categories, offering a continuous of similarity levels, so the moderating effect of this variable is analyzed. Results show that: (i) dependent variables are reinforced when junior brands are perceived as very similar, and diluted above some degree of dissimilarity; (ii) dilution increases the more dissimilar the junior brand. However, although they have a high degree of dissimilarity, cases of presumable tarnishment, might not always produce dilution. Besides, they suggest that the effect induced by similarity is not linear. These findings are discussed through the lenses of marketing and psychology theories. The study represents a contribution to the field, providing evidence not only from blurring cases, but also from supposed tarnishing imitators, comparing their effects and showing the limited moderating effect of similarity. The boundary conditions of similarity effects in trademark dilution literature have not been discussed previously. Finally, main implications for managers are highlighted, given the negative effects that trademark dilution may entail at firm level.
\end{abstract}

Keywords: trademark dilution, blurring, tarnishment, brand equity, similarity.

Please cite the article as follows: Macías, W. and Cerviño, J. (2017), “Trademark dilution: comparing the effects of blurring and tarnishment cases over brand equity”, Management \& Marketing. Challenges for the Knowledge Society, Vol. 12, No.3, pp. 346-360. DOI: 10.1515/mmcks-2017-0021.

\section{Introduction}

According to Simonson (1993), trademark dilution is, in a general sense, a reduction in brand equity due to the unauthorized use of the trademark by third parties (junior brands). When a junior brand causes a weakening of famous brand associations, it is called dilution by blurring (Simonson, 1993; Peterson, Smith and Zerrillo, 1999). On the other hand, dilution by tarnishment is caused when a junior brand adds negative associations to a famous brand mental network, or modifies the positive ones, negatively affecting the brand evaluation (Simonson, 1993), attitudes and desired behavior of consumers (Jacoby, 2001). 
For example, Budweiser Laboratories Insecticide (Brauneis and Heald, 2011), or Victor's Little Secret sex-related products store (Nicoletti, 2010), could add negative associations to the brands' nodes Budweiser and Victoria's Secret, respectively, in consumer memory.

The brand is recognized as a set of product or service identifiers i.e. words, phrases, logos, product configuration (also known as trade dress), colors, sounds and scents, which identify a person or entity's goods or services (Aaker, 1991; Kotler, 1991; Long, 2006). From the consumer's point of view, a brand can be defined as the total accumulation of all his/her experiences, built at all instances of interaction with (or exposure to) the brand (Kapferer, 2004). Once an identifier, or a combination of them, is legally registered to distinguish products or services from a manufacturer, it is known as a trademark that is protected by intellectual property rights. As such, trademarks can be owned, licensed, bought, sold, and used as collateral (Baird, 2010). One of the rights the owner of a trademark has, is to protect it against dilution caused by a third party.

The topic of trademark dilution is focused on famous brands, but there is no straightforward definition of "famous". Instead of famous brands, the World Intellectual Property Organization (2000) defines a well-known brand in terms of several considerations, such as the degree of recognition in the relevant sector of the public, the value of the brand, the geographical area of use of the brand, the geographical reach of advertising and promotions, amongst others. The U.S. Trademark Dilution Revision Act of 2006 states that a brand is famous "if it is widely recognized by the general consuming public of the United States as a designation of source of the goods or services of the mark's owner" (emphasis added), and then also gives a set of considerations a court should observe for determining the requisite degree of recognition (Civic Impulse, 2017). For the purpose of this study, famous brands are brands that are among the most used and recalled by consumers, within a product category.

Reconciling conceptualizations of several authors (Aaker, 1991; Farquhar 1989; Keller, 1993), this study defines brand equity from a consumer perspective as the perceived added value that a brand gives to a product, when compared to the same unbranded product. Consumer perceived added value is characterized by positive reactions towards the brand, such as buying more branded products, the willingness to pay price premiums and positive word of mouth. Although Aaker and Keller propose different multidimensional conceptualizations for brand equity, they concur that associations are pillars for building brand equity, something also shared by Simonson (1993), when explaining the process by which trademarks dilute. Associations represent the links between the brand and product attributes, sensations or experiences (Aaker, 1991), and these associations could vary in favorability, uniqueness and strength (Keller, 1993). Precisely, when understanding trademark dilution as the weakening and injury to the beliefs and feelings that consumers hold regarding a famous brand (i.e. associations). It can be argued that the harm could extrapolate to how consumers intend to behave toward that brand, e.g. reducing their purchase intention or increasing the possibility of negative word of mouth (Jacoby, 2008), which would constitute an important concern for managers of firms.

Trademark dilution has received attention not only from marketing and management, but also from the legal field. There is a debate among legal scholars on whether the anti-dilution law is necessary to protect famous trademarks. In a review of extant literature, Dworkowitz's (2011) summarizes that those who favor the anti-dilution law argue that the loss of a brand's distinctive power would result in a reduction of sales 
and, consequently, brand value, that is, that economic damage would have motivated the anti-dilution law.

On the other hand, those who are against the law consider that the harm posed by many of the examples of supposed dilutive products (e.g. Kodak pianos, Buick aspirin) is non-existent or, even if some negative effect exists over associations, it does not necessarily imply a reduction of purchase behavior in the marketplace. Therefore, they argue that legal protection is not justifiable (Moskin, 1993) under a theory of economic harm. The brand equity literature supports the assumption that an injury to associations translates into economic harm through a reduction in the branded product's purchase.

The U.S. Trademark Law prohibits registration of identical or similar (to already registered trademarks) brands when used in, or in connection with the goods of registered mark's owner. One may infer that - unless consumer confusion or mistake, or trademark dilution is likely to occur - registration of identical or similar brands in different product categories is possible (article 1, \#3D). As is explained by the U.S. Patent and Trademark Office, USPTO (2016), two identical or similar trademarks could coexist if "products and services are not related".

In Ecuador, the Intellectual Property Law allows the registration of new distinctive trademarks, establishing as exceptions (article 196) imitations, or those which are identical or similar to previously registered trademarks which identify the same products or services, or "products or services in respect of whose use may cause confusion or association with such mark; or may cause damage to its owner by diluting its distinctive strength or commercial value". In other words, the registration of the same or similar trademarks in different product categories is feasible, unless likely confusion or dilution is presumed.

In addition to cases of identical or similar brands in other categories of products, which may eventually be registered in some countries (such as the U.S. and Ecuador), there may also be cases of unauthorized use of famous trademarks in similar or different products. In summary, cases such as those illustrated in this study are likely to be seen in the market. Dilution could occur not only due to new registered trademarks, but also with unauthorized users of a well-established trademark.

Empirically, blurring has received the greater attention from scholars who have shown that junior brands weaken associations (Morrin and Jacoby, 2000; Morrin, Lee and Allenby, 2006; Pullig, Simmons and Netemeyer, 2006), dilute brand personality (Choy and Kim, 2013) and brand equity (Macías and Cerviño, 2017), and reduce purchase intention (Choy and Kim, 2013; Pullig et al., 2006) and purchase behavior (Macías and Cerviño, 2017). Several studies focused on blurring cases have also shown that dilution is alleviated the more similar that the famous trademark and the junior brand are (Macías and Cerviño, 2017; Morrin and Jacoby, 2000; Pullig et al., 2006). Apart from Macías and Balcázar (2016), there is a general lack of research about presumable tarnishment cases. Tarnishment cases typically relate to unsavory or unwholesome products or services, parodies or criticism (Bradford, 2008; Long, 2006), which may imply a high degree of dissimilarity with famous trademarks' product category or image, despite the use of some of its brand identifiers, such as its brand name, logo or lemma.

This indicates that an evident gap in the literature is the comparative analysis of the dilutive effects of presumable blurring and tarnishment cases. Following Simonson's definition of dilution, these effects should be evaluated not only over brand associations' 
metrics, but also over a brand equity construct. Therefore, this study aims to analyze how junior brands (blurring and tarnishment cases) affect famous trademarks' brand equity and strength of associations, considering the variable level of similarity that these junior brands may have. The hypotheses are that junior brands, either blurring or tarnishment cases, weaken famous brands' associations and dilute brand equity; that these negative effects increase the more dissimilar the junior brands are; and, presumed tarnishment by junior brands, when surpassing a threshold of dissimilarity, reduce or annul their dilutive effect.

To delimit the scope of this article, the cases presented for the study of dilution relate to the use of identical or similar brand names in different product categories. Highly familiar brands are used as famous trademarks. This study enriches the trademark dilution literature and bring more elements to the current debate regarding the level of harm that junior brands represent for holders of famous trademark.

\section{Literature review}

\section{Associative Network Model and trademark dilution}

According to the Associative Network Model (ANM) (Anderson, 1983; Teichert and Schöntag, 2010), information in the consumer's memory is stored in networks consisting of nodes (e.g. a famous brand and its distinctive aspects, such as product category and attributes, beliefs, sensations, etc.) connected by links (associations). When a junior brand emerges in another product category with some attributes (similar or not to those of the famous brand), new associations are added to the existing network or actual associations could be modified. When the consumer thinks about the brand, all associations compete for activation in the memory, thereby weakening the famous brand's associations by a reduction in the likelihood or speed of retrieval (Burke and Srull, 1988). This theory about the effect of junior brands on strength of associations has been supported by previous research, using blurring cases (Morrin and Jacoby, 2000; Morrin et al., 2006; Pullig et al., 2006). One of our arguments is that presumable tarnishment cases could also weaken actual associations, since new associations (regardless of their content) are attached to the brand node. In the process of evaluating dilution, or tarnishment, as explained by Simonson (1993), one can understand that tarnishment is a special case of blurring. Thus, it is hypothesized that:

H1: the emergence of junior brands, in cases of either blurring or tarnishment, weakens a famous brand's associations.

\section{Dilution of Brand Equity}

As explained in the introduction, this construct reflects the added value of the brand, perceived by the consumer, when compared to the same unbranded product (Aaker, 1991; Farquhar, 1989; Keller, 1993). Although Aaker (1991) and Keller (1993) have discussed that brand equity is supported by several dimensions, the conceptualization chosen for this study's purpose emphasizes the overall evaluation of the brand and not its sources (except strength of associations). We suggest it is an evaluative construct that could reflect the impact of a tarnishing brand, as it is defined as one that affects brand evaluation.

Aaker (1991), Keller (1993) and Macías and Cerviño (2017) explain that one of the pillars of brand equity is strong associations. When associations are weakened, they could be less salient in consumer memory during an evaluative task. Empirical evidence for blurring cases shows that brand equity could be diluted and purchase decisions could be 
affected due to consumers being exposed to junior brands (Macías and Cerviño, 2017). Moreover, when referring to tarnishment cases, it should be noticed that these types of brands would not only weaken the original associations by adding new associations to the brand node, but also the nature of the new aspects (negative or unpleasant) would affect the current perceptions towards the famous brand, reducing its global evaluation. Therefore, the second hypothesis is:

$\mathrm{H} 2$ : the emergence of junior brands, either in blurring or tarnishment cases, dilutes a famous brand's equity.

\section{Similarity, trademark dilution and the subtyping model}

Brand image is based on specific associations related to product category, attributes or benefits (Keller, 1993), many of them being brand-specific associations that distinguish the brand from other brands. Image similarity refers to consumers' perceptions of the similarity between brands images, for example, a parent brand and an extension (Bhat and Reddy, 2001), or as in the case of this study, a famous brand and its imitator.

Based on the ANM, when the perceived similarity between a JB and a famous brand increases, there are more interconnected nodes (nodes relating to all similar aspects) in the brand network (Jacoby, 2001), so the likelihood of retrieving original brand associations when the brand is triggered may not be reduced (Humphreys et al., 2000; Pullig et al., 2006). This means that lower dilution is expected, the less dissimilar that the JB and the famous brand are. Empirical studies on trademark dilution with blurring cases show evidence in this line (Morrin and Jacoby, 2000; Pullig et al., 2006; Macías and Cerviño, 2017). Considering the positive relation described between strength of associations and brand equity, the moderating effect of similarity is also predicted for the later construct. The following hypotheses summarize these arguments:

H3: When perceived similarity between a JB and a famous brand increases, either in blurring or tarnishment cases, weakening of associations reduces.

H4: When perceived similarity between a JB and a famous brand increases, either in blurring or tarnishment cases, dilution of brand equity reduces.

On the other hand, presumable tarnishing JBs use certain elements of the famous brand - as in this study the brand name - but the type of product and attributes may likely be significantly distant from the famous brand. This high dissimilarity would suggest that the weakening of the associations should be high. Academic evidence of tarnishment studies is scarce. A study of a parody of a famous Mexican series showed that the evaluation of the original series and its characters was statistically equal among the viewers who saw the parody in comparison to those who did not see it (Macías and Balcázar, 2016). The subtyping model for mental schemas can be used to explain this result. This model assumes that schemas are hierarchical structures that evolve through experience or new information (Weber and Crocker, 1983). When discrepant or incongruent information is acquired, and cannot be assimilated to be part of the established schema, a subcategory is created in order to differentiate (or discriminate) it from the upper category. In the context of this study, the junior brand could be interpreted as an exception and unrepresentative of a wellestablished famous brand. In this sense, the new information would be stored in a subcategory without the dilutive effect over famous brand's schema. Following this theory, we hypothesized that brand equity would be affected to some extent, depending on the 
degree of similarity of the JB, but that in extreme situations the dilutive effect can fade. The next hypothesis is:

H5: Tarnishing brands have less dilutive effect on famous brands' equity than blurring junior brands.

\section{Other moderators in trademark dilution studies}

Empirical studies have shown that consumer confusion about whether the two brands (the JB and famous brand) are from the same source (firm) relates positively to the level of dilution, but dilution could exist even if there is no confusion (Morrin et al., 2006). In the case of tarnishing JBs, Simonson (1993) explains, using the ANM, that transferring of evaluation from a junior to famous brand could occur even if the consumer is not confused, because of the similarities between the brands (e.g. brand name and logo similarities) that interconnect brand nodes. Moreover, the U.S. Trademark Dilution Revision Act of 2006 states that dilution could occur "regardless of the presence or absence of actual or likely confusion". For the purpose of this study, the level of confusion is not evaluated and the focus is on trademark dilution, similarity of JBs and the type of JBs.

The more familiar a brand is to a consumer, the more stable is the associated knowledge structure, which in turn is less likely to be changed (Choy and Kim, 2013). Morrin and Jacoby (2000) and Morrin et al. (2006) showed that familiarity with a brand is negatively associated to dilution. Considering that famous brands are those which are typically threatened by imitators or free riders, the focus of this study is on famous brands. This implies that the variable familiarity is controlled at high levels.

\section{Methodology}

\section{Experimental design and data collection}

An experimental between-subjects approach was taken in order to evaluate the effect of junior brands on famous brands. First, two focus groups (men and women) and a pretest $(n=59)$ among undergraduates were performed to select two most recognizable brands from two of the most frequently used product categories and to identify the correspondent distinctive attributes. It is worth mentioning that these brands are also among the most recognizable nationwide. BIC ranked first among the most recognizable brands in "school and office products" in a national ranking in 2017 (Vistazo, 2017). Rexona ranked fourth among "personal cleaning" brands, but was the most recognizable brand in the "deodorants" subcategory (Vistazo, 2017).

Table 1 summarizes the selections made, including the proposed blurring and tarnishing junior brands (product categories and attributes). Two graphic designers elaborated visual advertisements for famous, junior and other brands which were used as distractors.

Table 1. Selections made for famous and junior brands

\begin{tabular}{|l|c|c|}
\hline \multirow{2}{*}{} & \multicolumn{2}{|c|}{ Famous brands } \\
\cline { 2 - 3 } & BIC & Rexona* \\
\hline $\begin{array}{l}\text { Product category and main } \\
\text { attributes }\end{array}$ & $\begin{array}{c}\text { Pen, economical, high } \\
\text { quality, durable }\end{array}$ & $\begin{array}{c}\text { Deodorant, maximum } \\
\text { protection, good } \\
\text { fragrances, effective }\end{array}$ \\
\hline Blurring junior brands: & & \\
\hline
\end{tabular}




\begin{tabular}{|l|l|c|c|}
\hline $\begin{array}{l}\text { low } \\
\text { product } \\
\text { similarity }\end{array}$ & $\begin{array}{l}\text { low attribute } \\
\text { similarity }\end{array}$ & $\begin{array}{c}\text { Watch, sophisticated look, } \\
\text { not water-resistant }\end{array}$ & $\begin{array}{c}\text { Body wipes, unscented, } \\
\text { momentary cleaning }\end{array}$ \\
\cline { 2 - 4 } & $\begin{array}{l}\text { high attribute } \\
\text { similarity }\end{array}$ & $\begin{array}{c}\text { Watch, inexpensive, it never } \\
\text { fails }\end{array}$ & $\begin{array}{c}\text { Body wipes, great scents, } \\
\text { skin protection }\end{array}$ \\
\hline $\begin{array}{l}\text { high } \\
\text { product } \\
\text { similarity }\end{array}$ & $\begin{array}{l}\text { low attribute } \\
\text { similarity }\end{array}$ & $\begin{array}{c}\text { Tablet pen, elegant, limited } \\
\text { operating system } \\
\text { compatibility }\end{array}$ & $\begin{array}{c}\text { Eau de toilette, for kids, } \\
\text { kids scent (lavender) }\end{array}$ \\
\cline { 2 - 4 } & $\begin{array}{l}\text { high attribute } \\
\text { similarity }\end{array}$ & $\begin{array}{c}\text { Tablet pen, inexpensive, it } \\
\text { never fails }\end{array}$ & $\begin{array}{c}\text { Eau de toilette, great scents, } \\
\text { long lasting }\end{array}$ \\
\hline Tarnishing junior brands: & $\begin{array}{c}\text { Dr. BIC fleet enema, for } \\
\text { constipation, it does not fail }\end{array}$ & $\begin{array}{c}\text { Rexona insecticide, it } \\
\text { eliminates all kinds of } \\
\text { insects, it does not leave } \\
\text { you unprotected }\end{array}$ \\
\hline
\end{tabular}

* Known as Degree or Sure in other countries. Source: Authors' own research.

A random sample of course groups from a large university in Ecuador were selected, and 372 undergraduate students $\left(\bar{X}_{a g e}=20.5 ;\right.$ S.D. $\left.=2.47 ; \%_{F E M A L E}=63.7 \%\right)$ were randomly assigned to one of the 12 experimental groups: 2 brands (BIC, Rexona) $\times 6$ exposure (exposed to famous brand, exposed to $\mathrm{JB}_{1}, \mathrm{JB}_{2}, \ldots, \mathrm{JB}_{5}$ ) conditions. After seeing a set of three ads (famous or junior brand plus two distractor brands), a web-based questionnaire developed on Jotform $\AA$ was provided with demographic and filter questions, and questions related to the study's variables. Strength of associations and brand equity were measured with 3 and 4 items, respectively, from Yoo, Donthu and Lee (2000). The measurement of brand equity suggested by Yoo et al. aligns to the conceptualization adopted in this study and has been used and validated in several other studies about brand equity (Yoo and Donthu, 2001; Washburn and Plank, 2002; Buil, de Chernatony and Martínez, 2008). Perceived image similarity was measured with 2 items (Bhat and Reddy, 2001) only for those participants who were exposed to JBs. For model testing, similarity was recoded and interpreted as dissimilarity. Participants also reported how familiar they were with each of the famous brands (1=Not at all familiar - 7=Very familiar) (Choi et al., 2014; Morrin, 1999; Reinholtz, Bartels and Parker, 2015). Table 2 shows a list of the items used.

Table 2. Items for study constructs

\begin{tabular}{|c|c|c|c|}
\hline \multicolumn{2}{|c|}{ Construct: reliability and validity measures, items } & Scale & $\begin{array}{l}\text { Factor } \\
\text { loadings }\end{array}$ \\
\hline \multirow{2}{*}{\multicolumn{4}{|c|}{$\begin{array}{l}\text { Strength of associations (STASS) (Yoo et al., 2000): } \\
\text { CR=0.737; AVE=0.59; MSV=0.489 }\end{array}$}} \\
\hline & & & \\
\hline stass1 & $\begin{array}{l}\text { Some characteristics of (FB's name) come to my mind } \\
\text { quickly. }\end{array}$ & \multirow{3}{*}{$\begin{array}{c}\text { (1=Totally } \\
\text { disagree - } \\
\text { 7=Totally } \\
\text { agree) }\end{array}$} & 0.882 \\
\hline stass2 & I can quickly recall the symbol or logo of (FB's name). & & 0.634 \\
\hline stass $3^{*}$ & I have difficulty in imagining (FB's name) in my mind. & & - \\
\hline \multirow{2}{*}{\multicolumn{4}{|c|}{$\begin{array}{l}\text { Brand Equity (BE) (Yoo et al., 2000): } \\
\text { CR=0.833; AVE=0.556; MSV=0.489 }\end{array}$}} \\
\hline & & & \\
\hline be1 & $\begin{array}{l}\text { It makes sense to buy (FB's name) instead of any } \\
\text { other brand, even if they are the same }\end{array}$ & $\begin{array}{l}\text { (1=Totally } \\
\text { disagree - }\end{array}$ & 0.71 \\
\hline
\end{tabular}




\begin{tabular}{|c|c|c|c|}
\hline be2 & $\begin{array}{l}\text { Even if another brand has the same features as (FB's } \\
\text { name), I would prefer to buy (FB's name) }\end{array}$ & \multirow[t]{3}{*}{$\begin{array}{l}7=\text { Totally } \\
\text { agree) }\end{array}$} & 0.817 \\
\hline be3 & $\begin{array}{l}\text { If there is another brand as good as (FB's name), I } \\
\text { prefer to buy (FB's name) }\end{array}$ & & 0.739 \\
\hline be4 & $\begin{array}{l}\text { If another brand is not different from (FB's name) in } \\
\text { any way, it seems smarter to purchase (FB's name) }\end{array}$ & & 0.711 \\
\hline \multicolumn{4}{|c|}{$\begin{array}{l}\text { Similarity (SIM) (Bhat and Reddy, 2001): } \\
\text { CR=0.856; AVE }=0.752 ; \mathrm{MSV}=0.028\end{array}$} \\
\hline $\operatorname{sim} 1$ & $\begin{array}{l}\text { (JB's product category + JB's name) and (FB's product } \\
\text { category + FB's name) have similar images. }\end{array}$ & \multirow{2}{*}{$\begin{array}{c}\text { (1=Totally } \\
\text { disagree - } \\
7=\text { Totally } \\
\text { agree })\end{array}$} & 0.988 \\
\hline $\operatorname{sim} 2$ & $\begin{array}{l}\text { (JB's product category + JB's name) conveysthe same } \\
\text { impressions for me as (FB's product category + FB's } \\
\text { name). }\end{array}$ & & 0.727 \\
\hline
\end{tabular}

The questionnaire was translated by a professional translator from Ecuador, then checked by a marketing professor for conceptual equivalence, following Douglas and Craig (2007), and, finally, back-translated to the English by a professional translator from the United States. Both translators work for the Center for Foreign Languages (CELEX) of Escuela Superior Politécnica del Litoral (ESPOL). The back-translated and original versions of the questionnaire showed a high level of coincidence.

\section{Methods}

A confirmatory factor analysis (CFA) was carried out in AMOS software to test the measurement model. After this, construct reliability, convergent validity and discriminant validity were assessed using Composite Reliability Index (CR), Average Variance Extracted (AVE) and Maximum Shared Variance (MSV). Then, summated scales were calculated to obtain single measures for each variable.

In order to test the hypotheses, the following statistical models were proposed:

$$
\begin{gathered}
S T A S=\beta_{0}+\beta_{1} D_{J B}+\beta_{2} D I S S+\beta_{3}\left(D_{T A R} * D I S S\right)+\varepsilon \\
B E=\gamma_{0}+\gamma_{1} D_{J B}+\gamma_{2} D I S S+\gamma_{3}\left(D_{T A R} * D I S S\right)+\vartheta
\end{gathered}
$$

Where:

STAS is strength of associations

$B E$ is brand equity

$D_{J B}$ is a dummy that takes the value of 1 if the participant is exposed to a JB, and 0 otherwise.

DISS is the level of perceived dissimilarity of the JB when the participant is exposed to a JB. $D I S S=0$ otherwise.

$D_{T A R}$ is a dummy that takes the value of 1 if the participant is exposed to a presumable tarnishing JB, and 0 otherwise. $D_{T A R}$ is included interacting with DISS, because the effect of presumable tarnishment JBs on brand equity depends on their level of dissimilarity.

Intercepts $\beta_{0}$ and $\gamma_{0}$ are average levels of dependent variables STAS and $B E$, respectively, among consumers who are not exposed to JBs. 
Coefficients $\beta_{1}$ and $\gamma_{1}$ are partial effects of JBs over famous brands' STAS and $B E$, respectively, regardless of the level of DISS.

Coefficients $\beta_{2}$ and $\gamma_{2}$ reflect the moderating effect of JBs' similarity. Since all JBs have some degree of dissimilarity, total effects of a non-tarnishing JB over a famous brand's STAS and BE are $\beta_{1}+\beta_{2}$ DISS and $\gamma_{1}+\gamma_{2}$ DISS, respectively. Dilution hypotheses (H1 and H2) imply that $\beta_{1}+\beta_{2}$ DISS $<0$ and $\gamma_{1}+\gamma_{2}$ DISS $<0$. The hypotheses that lower (greater) similarity (dissimilarity) is associated with greater dilution (H3 and H4) imply that $\beta_{2}$ and $\gamma_{2}$ are negative. If $\beta_{2}$ and $\gamma_{2}$ were not statistically significant, it implies that similarity does not moderate dilution and $\beta_{1}$ and $\gamma_{1}$ were average dilutive effects, rather than partial.

$\beta_{3}$ and $\gamma_{3}$ indicate whether supposedly tarnishing JBs (JBT) have different effects comparing to other JBs (blurring cases, $\mathrm{JB}_{\mathrm{B}}$ ). When analyzing strength of associations, a differential effect of a $\mathrm{JB}_{\mathrm{T}}$ versus a $\mathrm{JB}_{\mathrm{B}}$ was not hypothesized. That is, it is expected that $\beta_{3}=0$. In the case of brand equity, we argued that the cases of tarnishment could be perceived by consumers as very dissimilar or not representative of the famous brand, subcategorizing them and minimizing the dilutive effect. That is, according to $\mathrm{H} 5, \gamma_{3}$ would be positive. Note that the effect of the term $\gamma_{3}\left(D_{T A R} * D I S S\right)$ is a positive function of the level of perceived dissimilarity of the $\mathrm{JB}_{\mathrm{T}}$.

Finally, $\varepsilon$ and $\vartheta$ are the errors of the models.

\section{Results}

\section{Confirmatory Factor Analysis}

The confirmatory factor analysis (CFA) showed, in its first iteration, low fit indexes. A specific problem was raised from a low factor loading for item stass3 $(<0.5)$. A new CFA without this item showed a better fit, but $p$-value is still too low $(<0.05)\left(\chi^{2}=58.04\right.$; d.f. $=17$; $\mathrm{p}$-value $=0.000$ ). As sample size increases above 200, Chi-square has a tendency to indicate significant differences in equivalent models (i.e., p-value suggests to reject the model) (Hair et al., 2010). Considering the large sample used in this study $(\mathrm{N}=372)$, other measures were used to assess model fit. CMIN/df is the Chi-square standardized by its degrees of freedom. Low levels (not below 1) imply a good fit, while values above 3 mean that the model requires improvement; however, some authors suggest a laxer threshold of 5 (Hair et al., 2010). The Goodness of Fit Index (GFI) is similar to the $R^{2}$ from a linear regression and must lie between 0 and 1 (perfect fit). AGFI is equal to the GFI adjusted by its degrees of freedom, and rewards parsimonious models. GFI and AGFI levels near or greater than 0.90 are recommended (Hair et al., 2010). The Comparative Fit Index (CFI) should be greater than 0.95 as an indicator of a good fit (Blunch, 2008). Root Mean Square Error (RMSEA) tries to correct the tendency of Chi-square of rejecting any model specified with a large enough sample (Hair et al., 2010). Values between 0.05 and 0.08 are considered acceptable (Hair et al., 2010), whereas values above 0.10 mean the model should be rejected (Blunch, 2008). Considering this set of measures, the measurement model has an acceptable fit (table 3).

All factor loadings were greater than the suggested level of 0.5 (Hair et al., 2010). All constructs had adequate levels of reliability (CR>0.70) (Hair et al., 2010). Fornell and Larker (1981) recommend that AVE should exceed 0.50 for convergent validity and should be greater than MSV to reflect discriminant validity. The values obtained by all constructs were above these thresholds (table 2). 
Table 3. Fit assessment for measurement model

\begin{tabular}{|l|l|l|}
\hline Measures & Threshold & $\begin{array}{l}\text { Measurement } \\
\text { model }\end{array}$ \\
\hline Chi-square $\left(\chi^{2}\right)$ & Low & 58.040 \\
\hline Degrees of freedom (d.f.) & - & 17 \\
\hline Chi-square probability (p-value) & $\geq 0.05$ & 0.000 \\
\hline CMIN/df & $\leq 3$ o 5 & 3.414 \\
\hline Goodness of Fit Index (GFI) & $\geq 0.90$ & 0.961 \\
\hline Adjusted Goodness of Fit Index (AGFI) & $\geq 0.90$ & 0.918 \\
\hline Comparative Fit Index (CFI) & $\geq 0.95$ & 0.964 \\
\hline Root Mean Square Error (RMSEA) & $\leq 0.08$ & 0.081 \\
\hline
\end{tabular}

* Not appropriate for large sample sizes.

Source: Hair et al. (2010), Blunch (2008), authors' own research.

\section{Preliminary checks}

Prior to models estimation, some checks were made to stimulus, to ensure internal reliability. Familiarity for brands and total sample is significantly greater than the scale mid-point (table 4). Dissimilarity of blurring JBs was manipulated to create variability. When compared to presumable tarnishing JBs, significant differences were found for every brand and total sample (table 5). Specifically, $\mathrm{JB}_{\mathrm{T}}$ are more dissimilar than $\mathrm{JB}_{\mathrm{B}}$.

Table 4. Brands' familiarity

\begin{tabular}{|l|l|l|l|}
\hline Statistics & BIC & Rexona & Total sample \\
\hline $\bar{X}_{\text {fam }}$ & 6.41 & 4.67 & 5.53 \\
\hline$S . D$. & 0.97 & 1.78 & 1.68 \\
\hline$t\left(\mathrm{H}_{0}: \bar{X}_{\text {fam }}=4\right)$ & 33.64 & 5.18 & 17.60 \\
\hline$p$-value & 0.000 & 0.000 & 0.000 \\
\hline
\end{tabular}

Source: Authors' own research.

Table 5. Junior brands' dissimilarity

\begin{tabular}{|l|l|l|l|l|l|l|}
\hline \multirow{2}{*}{ Statistics } & \multicolumn{2}{|c|}{ BIC } & \multicolumn{2}{c|}{ Rexona } & \multicolumn{2}{c|}{ Total sample } \\
\cline { 2 - 7 } & Blurring & Tarnish. & Blurring & Tarnish. & Blurring & Tarnish. \\
\hline $\bar{X}_{\text {diss }}$ & 4.29 & 5.42 & 4.93 & 5.70 & 4.61 & 5.56 \\
\hline S.D. & 1.75 & 1.41 & 1.46 & 1.51 & 1.64 & 1.46 \\
\hline$t^{*}$ & -3.28 & -2.69 & -4.25 & 0.000 \\
\hline$p$-value & 0.001 & 0.008 & ${ }^{*}$ Calculated for $\mathrm{H}_{0}: \bar{X}_{\text {Blurring }}-\bar{X}_{\text {Tarnish. }}=0$ \\
\hline \multicolumn{5}{|c|}{ Source: Authors' own research. }
\end{tabular}

\section{Model results}

A summary of results is shown in table 6 . For the total sample, partial effects captured by $\beta_{1}$ and $\gamma_{1}$ are positive, while the effects that depend on dissimilarity are negative $\left(\beta_{2}\right.$ and $\left.\gamma_{2}\right)$. This means that there is a threshold of JB dissimilarity that triggers the dilutive effect. This result is interesting, since it implies that for low (high) levels of dissimilarity (similarity) of JBs, there is a reinforcement of famous brands, rather than dilution. 
Regarding presumable tarnishment JBs, coefficients $\beta_{3}$ and $\gamma_{3}$ are positive, indicating that the dilutive effect of tarnishing brands over strength of associations and brand equity is less than the effect produced by blurring brands. This difference increases as dissimilarity of $\mathrm{JB}_{\mathrm{T}}$ increases.

When replicating the analysis by brand, results about coefficients signs are the same, but some of them reduce or lack statistical significance. In the case of BIC pens, the differential effect of $\mathrm{JB}_{\mathrm{T}}$ over STASS $\left(\beta_{3}\right)$ is significant at $10 \%$. The partial effect of JBs over BE $\left(\gamma_{1}\right)$ is not significant. Thus only reinforcement of associations (but not BE) at low dissimilarity levels is expected. Using Rexona data, nor partial effect of JBs $\left(\beta_{1}\right)$, neither differential effect of $\mathrm{JB}_{\mathrm{T}}$ over STASS $\left(\beta_{3}\right)$ are significant. The partial positive effect of JBs over $\mathrm{BE}\left(\gamma_{1}\right)$ is significant al $10 \%$, but the differential effect of $\mathrm{JB}_{\mathrm{T}}\left(\gamma_{3}\right)$ is not significant.

Table 6. Estimates for study's models, by brand and total sample

\begin{tabular}{|l|l|l|l|l|l|l|}
\hline \multirow{2}{*}{ Model } & \multicolumn{2}{|c|}{ BIC } & \multicolumn{2}{c|}{ Rexona } & \multicolumn{2}{c|}{ Total Sample } \\
\cline { 2 - 7 } & Estimate & $\boldsymbol{p}$-value & Estimate & $\boldsymbol{p}$-value & Estimate & $\boldsymbol{p}$-value \\
\hline STASS & & & & & & \\
\hline$\beta_{0}$ & 5.62 & 0.000 & 5.10 & 0.000 & 5.36 & 0.000 \\
\hline$\beta_{1}$ & 0.80 & 0.029 & 0.87 & 0.118 & 1.07 & 0.002 \\
\hline$\beta_{2}$ & -0.14 & 0.020 & -0.29 & 0.002 & -0.27 & 0.000 \\
\hline$\beta_{3}$ & 0.09 & 0.072 & 0.07 & 0.224 & 0.08 & 0.041 \\
\hline$F$ & 2.52 & 0.060 & 4.39 & 0.005 & 8.11 & 0.000 \\
\hline$R^{2}$ & 0.04 & 0.07 & & 0.06 & \\
\hline BE & \multicolumn{7}{|l|}{} & & & & \\
\hline$\gamma_{0}$ & 4.78 & 0.000 & 4.40 & 0.000 & 4.59 & 0.000 \\
\hline$\gamma_{1}$ & 0.45 & 0.263 & 0.84 & 0.100 & 0.75 & 0.021 \\
\hline$\gamma_{2}$ & -0.16 & 0.019 & -0.29 & 0.001 & -0.25 & 0.000 \\
\hline$\gamma_{3}$ & 0.16 & 0.003 & 0.08 & 0.137 & 0.12 & 0.002 \\
\hline$F$ & 3.77 & 0.012 & 5.04 & 0.002 & 8.94 & 0.000 \\
\hline$R^{2}$ & 0.06 & 0.08 & & 0.07 & \\
\hline
\end{tabular}

Source: Authors' own research.

Further analysis evaluates the models with the dissimilarity means for the total sample, for purpose of comparison between experimental groups (table 7). The estimated values for strength of associations and brand equity show that presumable tarnishing brands do not dilute famous brands, considering dissimilarity means.

Table 7. Models estimates at groups' means

\begin{tabular}{|l|l|l|l|}
\hline \multirow{2}{*}{ Variables } & \multicolumn{3}{|c|}{ Total sample } \\
\cline { 2 - 4 } & Control & Blurring & Tarnish. \\
\hline$D_{J B}$ & 0 & 1 & 1 \\
\hline$D_{T A R}$ & 0 & 0 & 1 \\
\hline $\bar{X}_{\text {diss }}$ & 0.00 & 4.61 & 5.56 \\
\hline STASS (est.) & 5.36 & 5.16 & 5.35 \\
\hline BE (est.) & 4.59 & 4.18 & 4.59 \\
\hline \multicolumn{4}{|c|}{ Source: Authors' own research. }
\end{tabular}




\section{Conclusions}

These findings lead us to conclude that there is evidence for dilution hypotheses (H1 and H2) but where there exists a minimal level of dissimilarity with JBs. When consumers perceive JBs as very similar to famous brands, a reinforcement effect appears in the total sample. When analyzing by brand, only associations from the more familiar brand (BIC) were reinforced at low similarity levels. Similar results have been evidenced in other studies. Morrin et al. (2006) have shown that for more familiar brands, category recall probability increases after being exposed to JBs. Choy and Kim (2013) evidenced that brand personality is reinforced for more familiar brands, due to exposure to JBs, regardless of the level of similarity. However, for unfamiliar brands, only similar JBs reinforce a famous brand's personality, whereas dissimilar JBs dilute it.

Hypotheses $\mathrm{H} 3$ and $\mathrm{H} 4$ are also supported; the more dissimilar the JBs, the more dilution is expected. Finally, presumable tarnishing JBs, which have a higher level of dissimilarity than blurring JBs, could be less dilutive (H5 supported with total sample and one brand). This last result is consistent with the case of a Mexican famous television series that was not diluted by a parody (Macías and Balcázar, 2016). The subtyping model explains both findings, suggesting that consumers considered this new information as an exception of well-established brand's schemas. To date, several studies have shown that dilution increases with dissimilarity of junior brands. The main contribution of this study is to show the boundary conditions of similarity effects in trademark dilution, while comparing the consequences of presumed blurring and tarnishing junior brands on strength of associations and overall brand equity. This was possible with a design that carefully manipulated the degree of similarity of junior brands, considering similar and dissimilar product categories and attributes.

Some limitations of this study should be mentioned. Despite the criticism of the artificiality of experiments (fictitious JBs, controlled environment), this approach allows the design of imitators based on the variables of interest. Cases like those analyzed by Macías and Balcázar (2016) are difficult to obtain in other contexts different from the Internet, and the manipulation of variables of interest is not possible. Data from graduate students is criticized for its lack of generalization, but Calder, Phillips and Tybout (1981) justify its use in research aiming to test theories, since it provides an opportunity to reject hypotheses.

Further research could be valuable in investigating specific aspects of JBs that produce a tarnishing effect. Using the famous brand in a parody or in an unpleasant product may not be enough to cause damage to its brand equity. Another interesting avenue of research could be to compare these observed effects in other product types, like shopping and specially, where consumers make more comparative efforts and are used to being more involved with product categories. According to the Elaboration Likelihood Model (Petty, Cacioppo and Schumann, 1983; Petty and Cacioppo, 1984), more involved consumers are less susceptible to modify their beliefs and attitudes due to new information (like that coming from JBs). Our results cannot be generalized to non-convenience product categories.

The emergence of new JBs (registered or not by intellectual property authorities) in other product categories is feasible, given the possibility implicit in some legal frameworks. Thus, trademark dilution is a potential problem for firms. According to these results, the strength of a brand's associations and its overall perception of added value are not affected by all JBs that emerge in the market. High consumer familiarity with the brand, and JBs with 
extreme levels of similarity/dissimilarity make dilution less likely. However, further research is needed to analyze which brand equity dimensions are diluted by JBs and how they are related to overall brand equity dilution, given the limitation that only the latter construct was used in this study. Although we have provided evidence that the similarity effect is limited to some extent, we have not predicted a threshold for the level of similarity over which dilution fades. An implication for managers is that they should continuously monitor consumer beliefs and evaluation of the brand (brand tracking) in order to identify if presumable diluting JBs are actually imposing a negative effect that deserve a legal response. Since trademark litigation carries cost implications, managers should be aware that not every JB represents a threat for famous brands' equity.

\section{References}

Aaker, D. (1991), "Managing brand equity: Capitalizing on the value of a brand name", New York: The Free Press.

Anderson, J. (1983), "The architecture of cognition", Cambridge, MA Harvard University Press.

Baird, S. (2010), "Brands and Trademarks: the legal implications of branding", In B. Loken, $R$. Ahluwalia, and M. Houston (Eds.), Brands and brand management: Contemporary research perspective, New York, NY: Taylor \& Francis.

Bhat, S. and Reddy, S. (2001), "The impact of parent brand attribute associations and effect on brand extension evaluation", Journal of Business Research, Vol. 53, No. 3, pp. 111122.

Bradford, L. (2008), "Emotion, dilution, and the trademark consumer", Berkeley Technology Law Journal, Vol. 23, No.3.

Blunch, N. (2008), Introduction to structural equation modelling using SPSS and AMOS. Sage.

Brauneis, R. and Heald, P. (2011), "Trademark infringement, trademark dilution, and the decline in sharing of famous brand names: an introduction and empirical study", Buffalo Law Review, Vol. 59, pp. 141.

Burke, R. and Srull, T. (1988), "Competitive interference and consumer memory for advertising", Journal of Consumer Research, Vol. 15, pp. 55-68.

Buil, I., de Chernatony, L. and Martínez, E. (2008), "A crossnational validation of the consumer-based brand equity scale. Journal of Product and Brand Management, Vol. 17, No. 6, pp. 384-92.

Calder, B., Phillips, L. and Tybout, A. (1981), "Designing research for application”, Journal of Consumer Research, Vol. 8, No. 2, pp. 197-207.

Choi J, L., Rangan, P., Chatterjee, P. and Singh, S. (2014), "The Odd-Ending Price Justification Effect: the Influence of Price-Endings on Hedonic and Utilitarian Consumption", Journal of the Academy of Marketing Sciences, Vol. 42, pp. 545-557.

Choy, M. and Kim, J. (2013), "New brands diluting the personality of existing brands", Journal of Brand Management, Vol. 20, pp. 590-607.

Civic Impulse (2017), H.R. 683 - 109th Congress: Trademark Dilution Revision Act of 2006. Retrieved from https://www.govtrack.us/congress/bills/109/hr683

Douglas, S. P., and Craig, C. S. (2007), "Collaborative and iterative translation: an alternative approach to back translation", Journal of International Marketing, Vol. 15, No. 1, pp. 30-43. 
Dworkwitz, A. (2011), "Ending Dilution Doublespeak: Reviving the Concept of Economic Harm in the Dilution Action", Texas Intellectual Property Law Journal, Vol. 20, pp. 25495.

Farquhar, P. (1989), "Managing brand equity", Marketing Research, 1, pp. 24-33.

Fornell, C., and Larcker, D. F. (1981), "Evaluating structural equation models with unobservable variables and measurement error", Journal of Marketing Research, Vol. 18, pp. 39-50.

Hair, J., Black, W., Babin, J. and Anderson, E. (2010), "Multivariate data analysis (7th ed.)", Englewood Cliffs: Prentice Hall.

Humphreys, M., Tehan, G., O'Shea, A. and Bolland, S. (2000), "Target similarity effects: Support for the parallel distributed processing assumptions", Memory and Cognition, Vol. 28, No.5, pp. 798-811.

Jacoby J. (2001), "The Psychological Foundations of Trademark Law: Secondary Meaning, Fame, Confusion and Dilution", The Trademark Reporter, Vol. 91, pp.1013-1071.

Jacoby, J. (2008), "Considering the who, what, when, where and how of measuring dilution", Santa Clara Computer and High Technology Law Journal, Vol. 24, No. 3, pp. 101-139.

Kapferer, J. (2004), "Brand NEW world, brand equity", The Economic Times, June 30, Mumbai.

Keller, K. (1993), “Conceptualizing, Measuring, Managing Customer-Based Brand Equity", Journal of Marketing, Vol. 57, pp. 1-22.

Kotler, P. (1991), "Marketing Management: Analysis, Planning, and Control", Prentice-Hall Inc., Englewood Cliffs.

Long, C. (2006), "Dilution”, Columbia Law Review, Vol. 106, No. 5, pp. 1029-1078.

Macías, W. and Balcázar, G. (2016), "Análisis de dilución de marcas: una parodia a El Chavo del 8", Comunicación y Sociedad, Vol. 27, pp. 175-195.

Macías, W. and Cerviño, J. (2017), "Trademark dilution and its practical effect on purchase decision", Spanish Journal of Marketing, Vol. 21, pp. 1-13.

Morrin, M. (1999), "The impact of brand extensions on parent brand memory structures and retrieval processes", Journal of Marketing Research, Vol. 36, pp. 517-525.

Morrin, M. and Jacoby, J. (2000), "Trademark Dilution: Empirical Measures for an Elusive Concept", Journal of Public Policy \& Marketing, Vol. 19, pp. 265-276.

Morrin, M., Lee, J. and Allenby, G. (2006), "Determinants of Trademark Dilution", Journal of Consumer Research, Vol. 33, pp. 248-257.

Moskin, J. (1993), "Dilution or Delusion: the Rational Limits of Trademark Protection", The Trademark Reporter, Vol. 83, pp. 122-148.

Nicoletti, D. (2010), "V Secret Catalogue, Inc. v. Moseley, 2010”, Finnegan Articles, pp. 3-6.

Peterson, R., Smith, K. and Zerrillo, P. (1999), "Trademark Dilution and the Practice of Marketing", Journal of the Academy of Marketing Science, Vol. 27, pp. 255-268.

Petty, R. and Cacioppo, J. (1984), "The effects of involvement on responses to argument quantity and quality: Central and peripheral routes to persuasion", Journal of Personality and Social Psychology, Vol. 46, pp. 69-81.

Petty, R., Cacioppo, J. and Schumann, D. (1983), "Central and peripheral routes to advertising effectiveness: The moderating role of involvement", Journal of Consumer Research, Vol. 10, pp. 135-146.

Pullig, C., Simmons, C. and Netemeyer, R. (2006), "Brand Dilution: When Do New Brands Hurt Existing Brands?", Journal of Marketing, Vol. 70, pp. 52-66. 
Reinholtz, N., Bartels, D. and Parker, J. (2015), “On the Mental Accounting of Restricted-Use Funds: How Gift Cards Change What People Purchase", Journal of Consumer Research, Vol. 42, pp. 596-614.

Simonson, A. (1993), "How and When Do Trademarks Dilute? A Behavioral Framework to judge 'Likelihood' of Dilution", The Trademark Reporter, Vol. 83, pp.149-174.

Teichert, T. and Schöntag, K. (2010), "Exploring consumer knowledge structures using associative network analysis", Psychology \& Marketing, Vol. 27, No.4, pp.369-398.

The United States Patent and Trademark Office (2009), "U.S. Trademark Law. Trademark Act of 1946, as amended". Retrieved from http://www.uspto.gov

The United States Patent and Trademark Office (2016), "Protecting Your Trademark, enhancing your rights through federal registration". Retrieved from http://www.uspto.gov

Vistazo (2017), "Y las marcas más recordadas en Ecuador son..." [on line]. Retrieved from: http://vistazo.com/seccion/pais/actualidad-nacional/y-las-marcas-masrecordadas-en-ecuador-son

Washburn, J., and Plank, E. (2002), "Measuring brand equity: An evaluation of a consumerbased brand equity scale", Journal of Marketing Theory and Practice, Vol. 10, pp. 4662.

Weber R. and Crocker J. (1983), "Cognitive Processes in the Revision of Stereotypic Beliefs", Journal of Personality and Social Psychology, Vol.45, pp. 961-977.

World Intellectual Property Organization (2000), "Joint Recommendation Concerning Provisions on the Protection of Well-Known Marks".

Yoo, B., and Donthu, N. (2001), "Developing and validating a multidimensional consumerbased brand equity scale", Journal of business research, Vol. 52, No. 1, pp. 1-14.

Yoo, B., Donthu, N. and Lee, S. (2000), "An examination of selected marketing mix elements and brand equity", Journal of the Academy of Marketing Science, Vol. 28, No. 2, pp. 195-211. 